Original article

\title{
ANALYTICAL STUDY OF ARCHAEOLOGICAL POTTERY BREAD MOULDS FROM MATARIYA, AIN SHAMS
}

\author{
Abdel Rahim, N.S. \\ Lecturer Department of Conservation, Faculty of Archaeology, Fayoum University, Egypt \\ drnagwagohar@hotmail.com
}

\begin{abstract}
This study dealt with the Archaeological pottery shreds which were found in the excavation done by the Supreme Council of Antiquities (SCA) in Matariya and Ain Shams regions. The analytical techniques used are the polarizing light microscope (PLM), scanning electron microscope (SEM) and X-ray diffraction technique (XRD) to determine the materials and manufacturing techniques used in these findings. It was found out that the discovered shreds comprise a group of pottery bread moulds belong to the Middle Kingdom (2040-1782 B.C). It was also found that the texture of the pottery were made using a large quantity of medium to coarse plant residues which is one of the most characteristic features of Nile fabrics. The colour of the pottery fracture is reddish to brown. The firing temperature was uneven and the hardness of the pottery is medium. The moulds were handmade shaping. All these characteristics are belonging to the Nile $C$ group. The two moulds were fully restored including cleaning, construction, completion and coloring.
\end{abstract}

Keywords: Pottery, bread mould, restoration, Mattarya, Ain shams, Middle Kingdom

\section{Introduction}

\subsection{The Archaeological and Historical Studies}

The area of Matarya and Ain Shams is an important part of the old City Helioplis., it is one of three major cities of ancient Egypt, along with Memphis and Thebes, located north- east of present -day Cairo $(30 \circ 05, \mathrm{~N} 31 \circ 20$, E). Nowadays the site is largely covered by the suburban Cairo settlement of elMatariya and Tell hisn [1]. Recently, the only standing monument is a large twelfth dynasty obelisk, dedicated by Senwosret I. and several old Kingdom tombs of high priests [2]. A Stella of Thutmose III, from the eighteenth dynasty, commemorates a wall that encloses the solar temple. Excavations have revealed some Ramesside construction -several temples and a cemetery for the Mnevis bulls [3]. There is a group of temples, houses, factories, glass and pottery perfume and furnaces for the preparation of bread inside the city walls. The city was largely destroyed during the Persian invasion of $525 \mathrm{BC}-343 \mathrm{BC}$. [4]. the city is one of the oldest cities in the religious history of ancient Egypt since the pre-history and across different periods. The city has got cultural importance of a systemic nature in all administrative, economic, 
social and religious aspects [5]. Analytical data of pottery composition is understood in its broadest sense including the composition of fillers, slips and decorative pigments as well as clay which is essential to understand the cultural process [6]. The properties of the clay differ from one type to another according to the difference in chemical composition; this greatly affects the degree of firing. The clay used in Egypt in manufacturing the pottery had two types: one of them is the clay which contains a large content of organic matters, iron elements and quartz .It exists in delta and Nile valley. The other type which contains organic matters, calcium components exists in Qena and Balas in Upper Egypt. Also, water significantly affects the characteristics of the clay used [7]. The division between clays is now so wall-established in Egyptian archaeology that attempting to change it would be counterproductive. The clays are size terms, for particles respectively $0.06-0.002 \mathrm{~mm}$ and $<0.002$ $\mathrm{mm}$ in diameter. The technology of pottery making has gained attention in terms of methods of shaping varying between the simple manual shaping and

\subsection{Documentation}

A set of pottery was found in Matreya and Ain shams, fig. (1). Their total number is fourteen cylindrical bread molds; differ in length ranging from $14 \mathrm{~cm}$ to $4.5 \mathrm{~cm}$ were discovered in the excavation area whose the use of a sheet, rope or molds or profile by using the wheel [8]. Temperature of $1000^{\circ} \mathrm{C}$ can be reached relatively easily with a simple up draught kiln, and the examination of Egyptian pottery by various re-firing techniques suggests that most firing temperature were well below this temperature. They found a mean maximum temperature for open firing of $860^{\circ} \mathrm{C}$ as high as $900^{\circ} \mathrm{C}$ but over $600^{\circ}$ $\mathrm{C}$ are generally sufficient to sinter clay and render it ceramic [9]. The deterioration factors of pottery antiques are divided into two parts. The Internal factors involve inhomogeneous in physical properties between the mineral and non-mineral contents in its structure, its crystalline shapes and its cohesion. They also include the manufacture faults done by the manufacturer or occurrence as a result of an external condition during the manufacturing process. The external factor includes physical and chemical factors, the effects of high temperature, humidity, air pollution, ground water which carries salts and also biological deterioration.

plane demonstrated in fig. (2-a, b). Fig. (3-a, b, c, d) describe some of the pieces individually. The general case of the objects was good except for some dusty dirt.

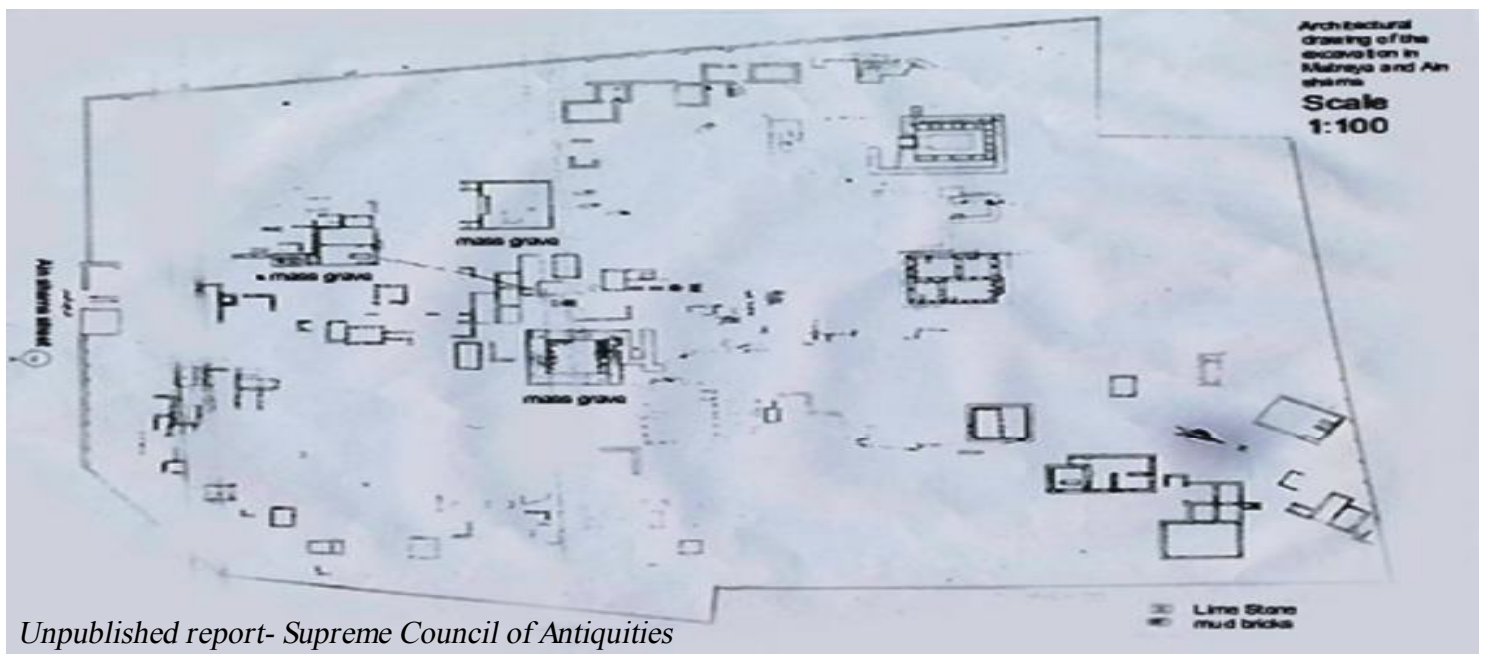

Figure (1) An architectural drawing of the excavation in Matreya and Ain shams 1:100 

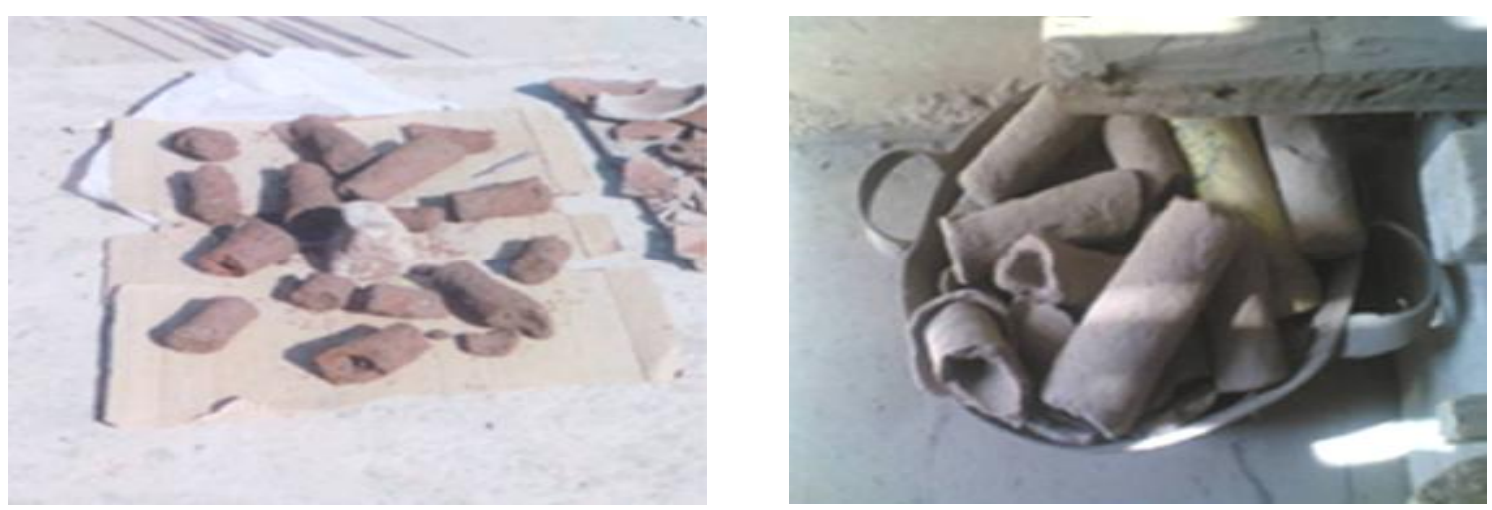

Figure $(2-a, b)$ The group of pottery in the excavation site.
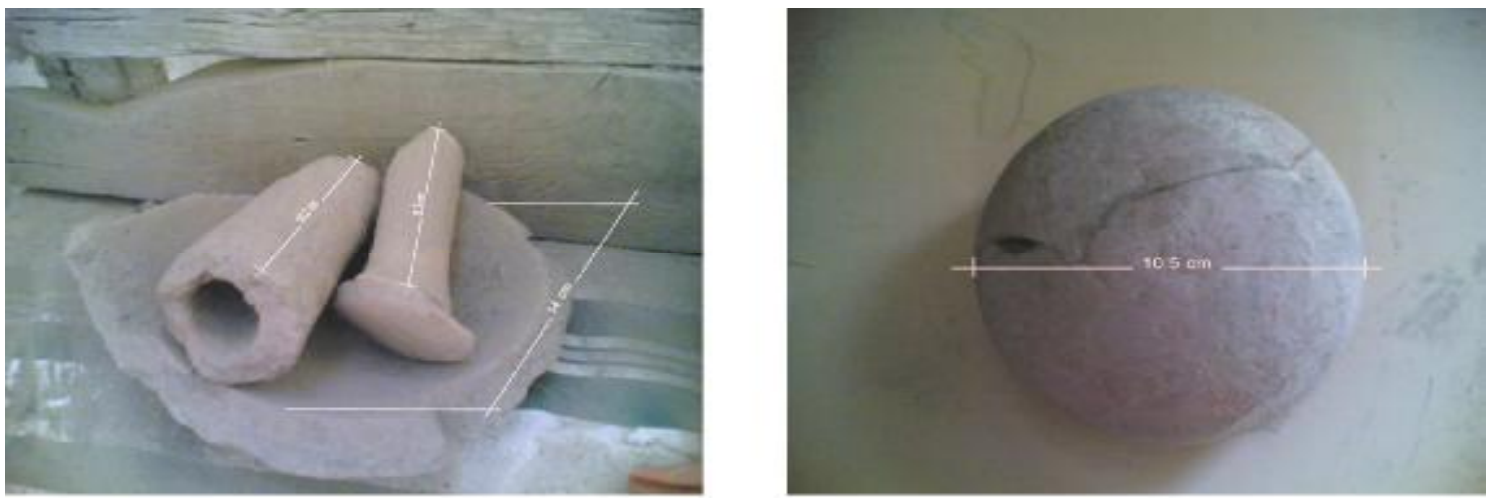

Figure (3-a) The group of pottery in the excavation site.
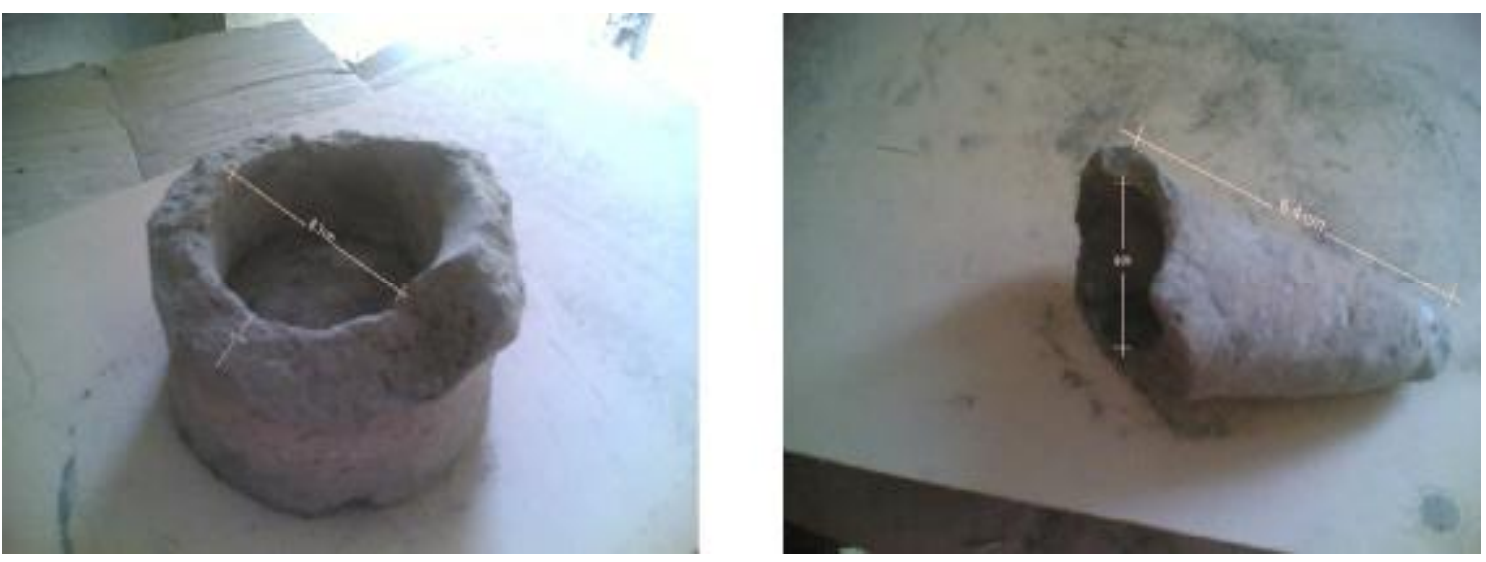

Figure (3-b) The group of pottery in the excavation site.
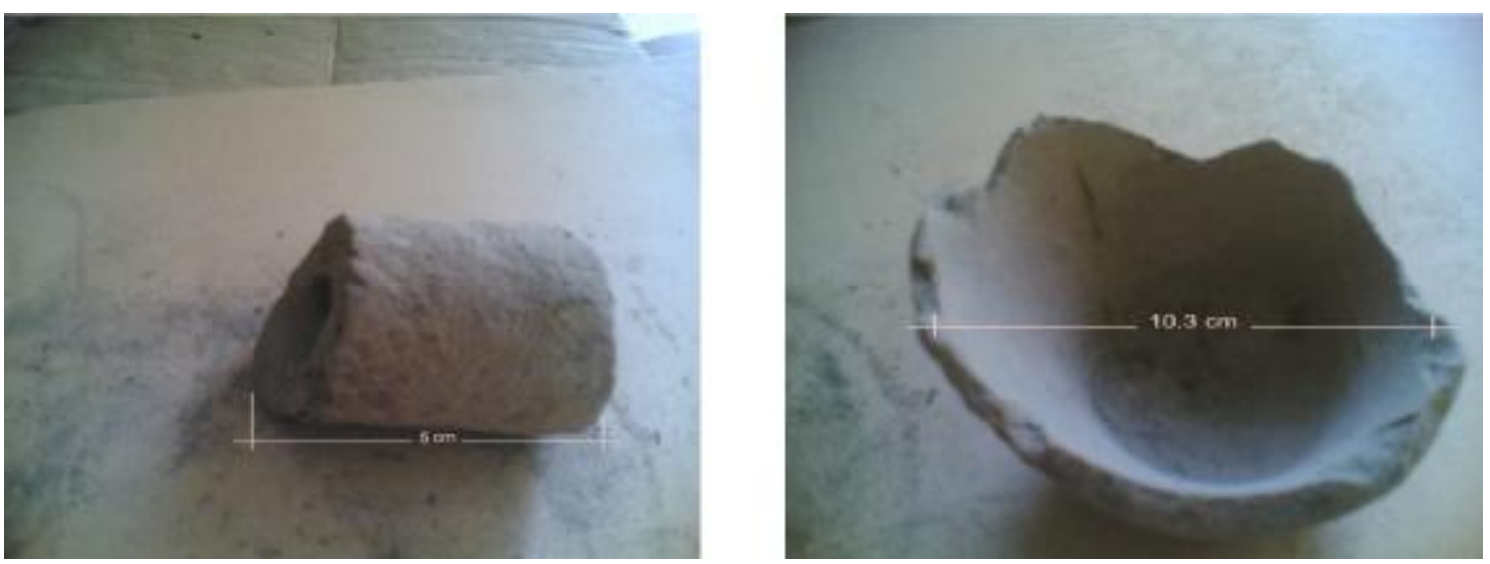

Figure (3-c) The group of pottery in the excavation site. 

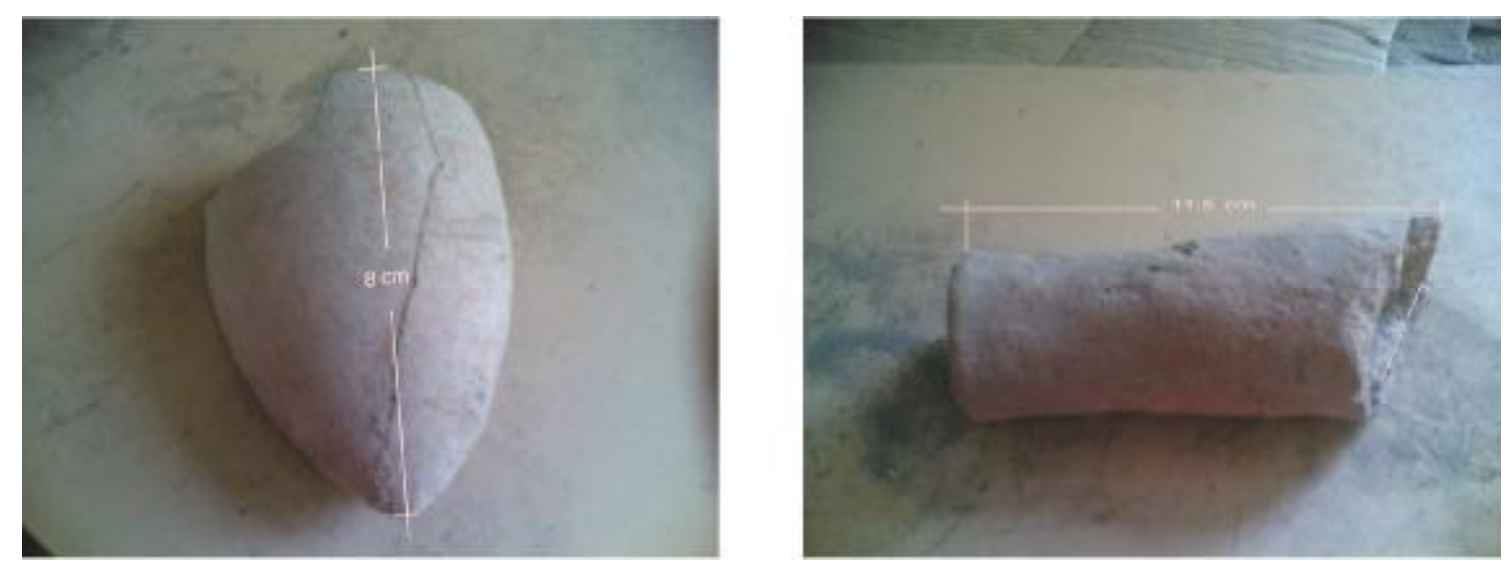

Figure (3-d) The group of pottery in the excavation site.

\subsection{The uses of the pottery}

Studying this collection and returning to many historical references and archaeological sites had been classified as templates for the bread moulds. These references confirmed that these bread moulds have evolved over eras of ancient Egypt, varying form of the Old Kingdom, the Middle Kingdom counterparts and in New Kingdom

\subsection{General description}

The moulds walls are about $1.3-2.2 \mathrm{~cm}$ thickness and with high porosity. They have medium hardness and reddish brown colour. The texture is varied indicating the shape, function and

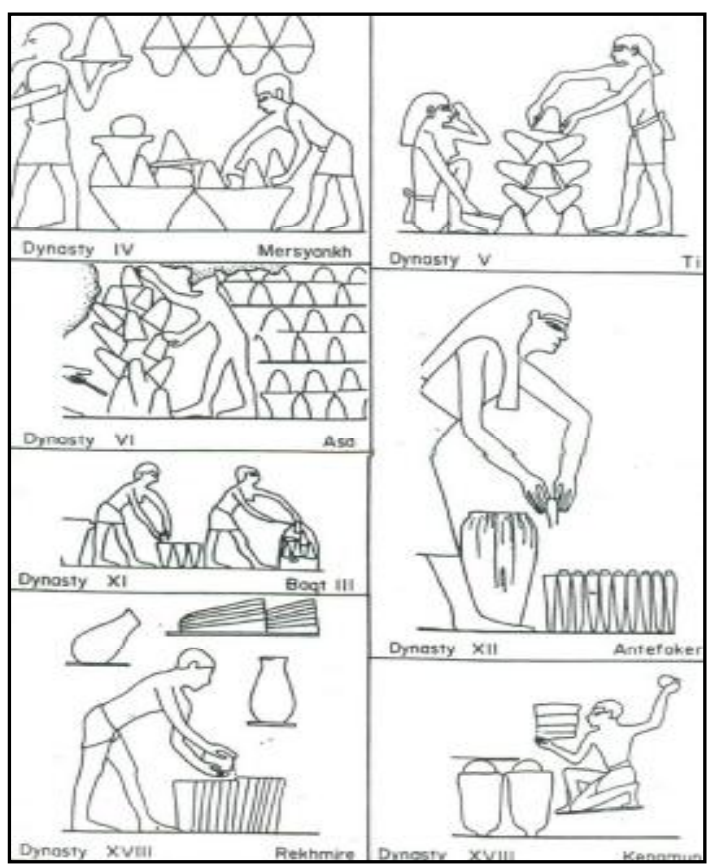

Figure (4) Baking scenes of King Amenemhet III (after Paice. 1989) forms. It will be remembered that the early bread moulds illustrated in Old Kingdom tombs were bell-shaped. By the end of the First Intermediate period, the form has become an elongated cone the next change perceived in the excavated pottery is the introduction of rounded case in the New Kingdom as shown in fig. $(4,5,6)$ [10], [11], [12].

manufacture of the moulds. We can see plant residues very easily inside the core of pottery. All the excavated shreds are plain with missing rims and hands.

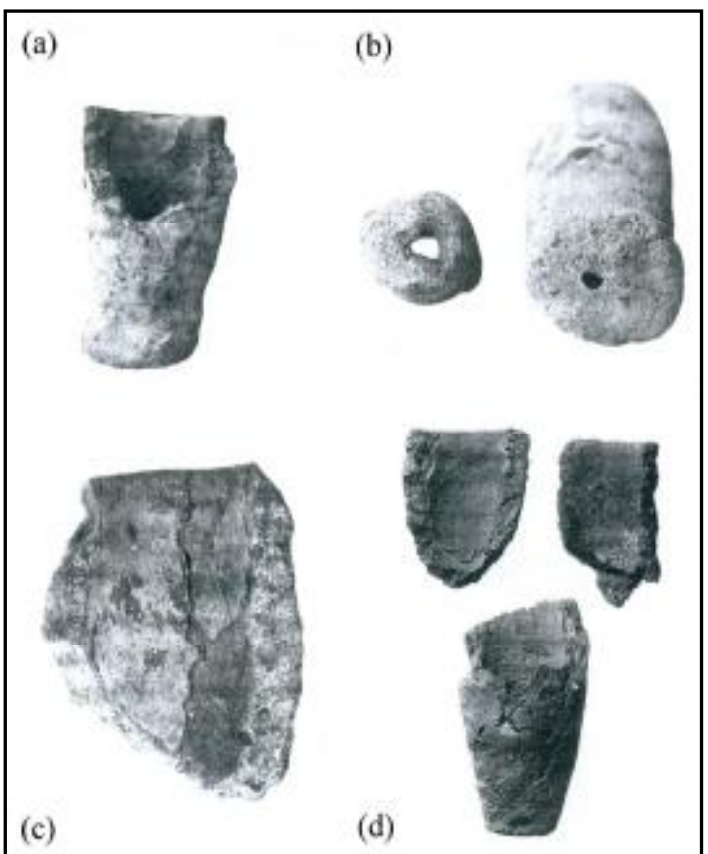

Figure (5 a, b, c) Middle Kingdom bread mould from Dendara (after Marchand, 2004) (d) from Dahshur (after, Arnold, 

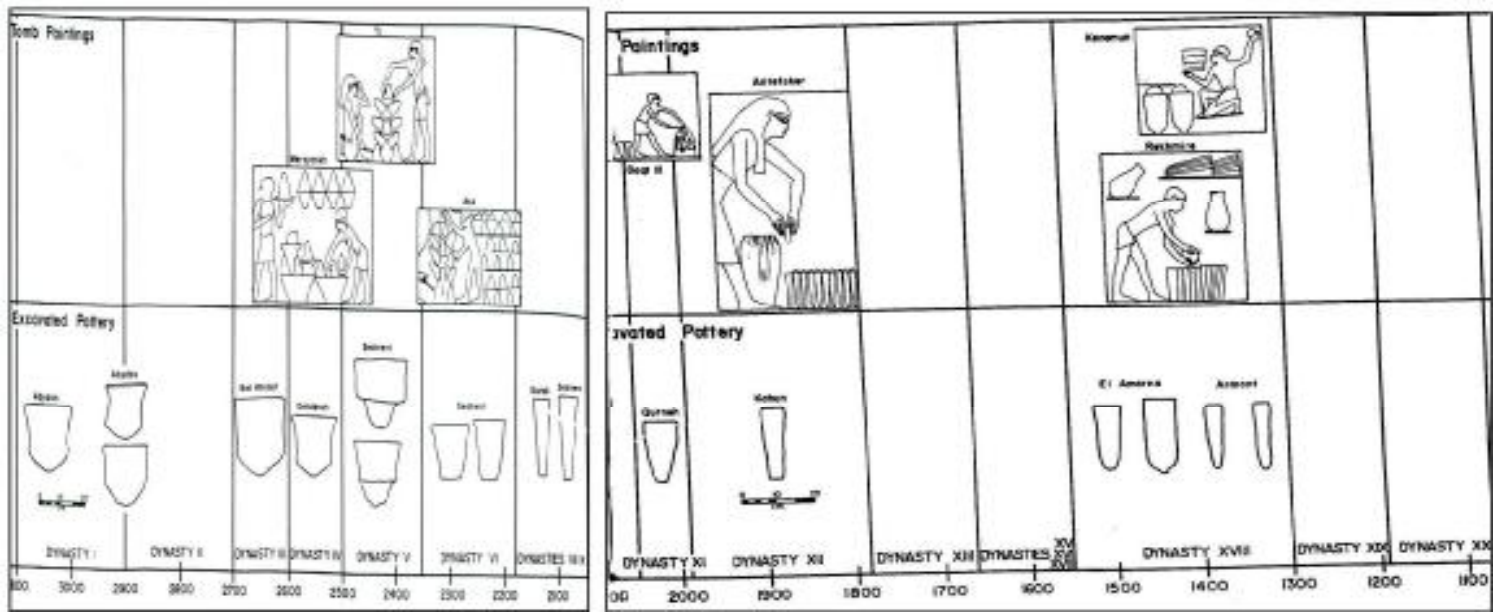

Figure (6) The development of bread moulds (after Paice, 1989)

\section{Materials and Methods}

\subsection{Visual Examination}

The sample was examined by naked eye as well as using magnifying lenses $\times 10$ to identify the type of component of the fabric of the moulds, an attempt to

\subsection{Polarizing Light Microscope}

This is the most useful way in the analysis of pottery which can identify the mineralogical composition of pottery, additives, particle size, large or

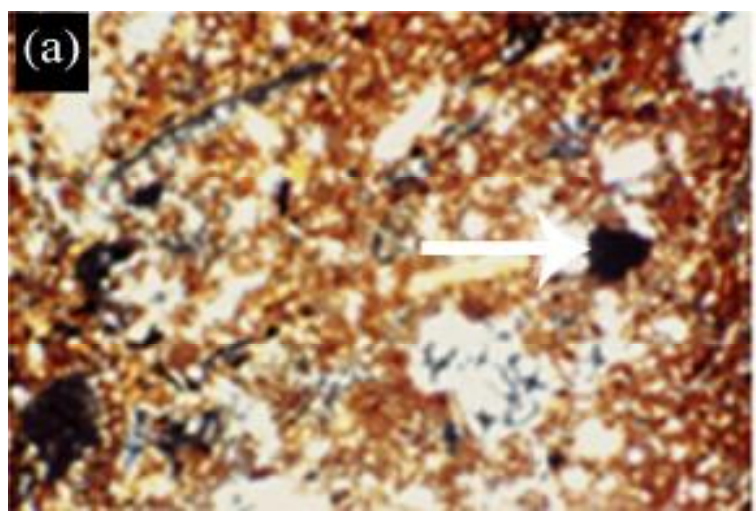

discover the structures, the rough and porous fabric, gaps. They were handmade, and not made using the wheel.

small, smooth or rough, signs of burning rates and iron oxides that give the color of pottery, as shown in fig. (7-a, b), (8-a, b).

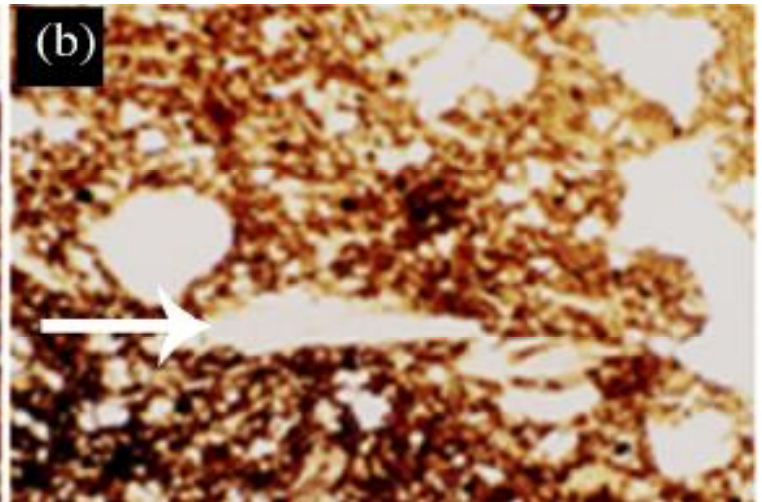

Figure (7) Shows the first mould (a) the grains of quartz and iron oxides and mica (b) the grains of quartz and iron oxides with a broken pottery
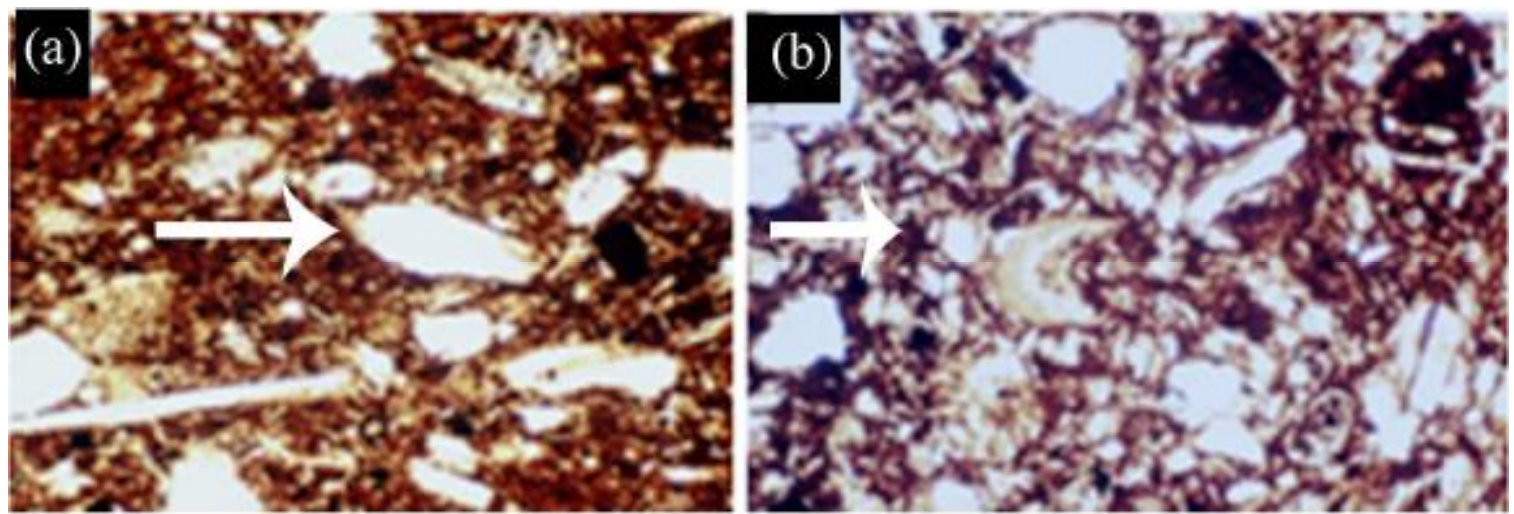

Figure (8) Shows the second mould (a) quartz grains and iron oxides (b) sharp quartz and iron oxides 


\subsection{Scanning Electron Microscope examination}

The electron microscope is one of the most important devices used to examine and analyze many of the archaeological

materials and give an idea about the surface of the mould, as shown in fig. (9-a, b, c), (10-a, b, c).
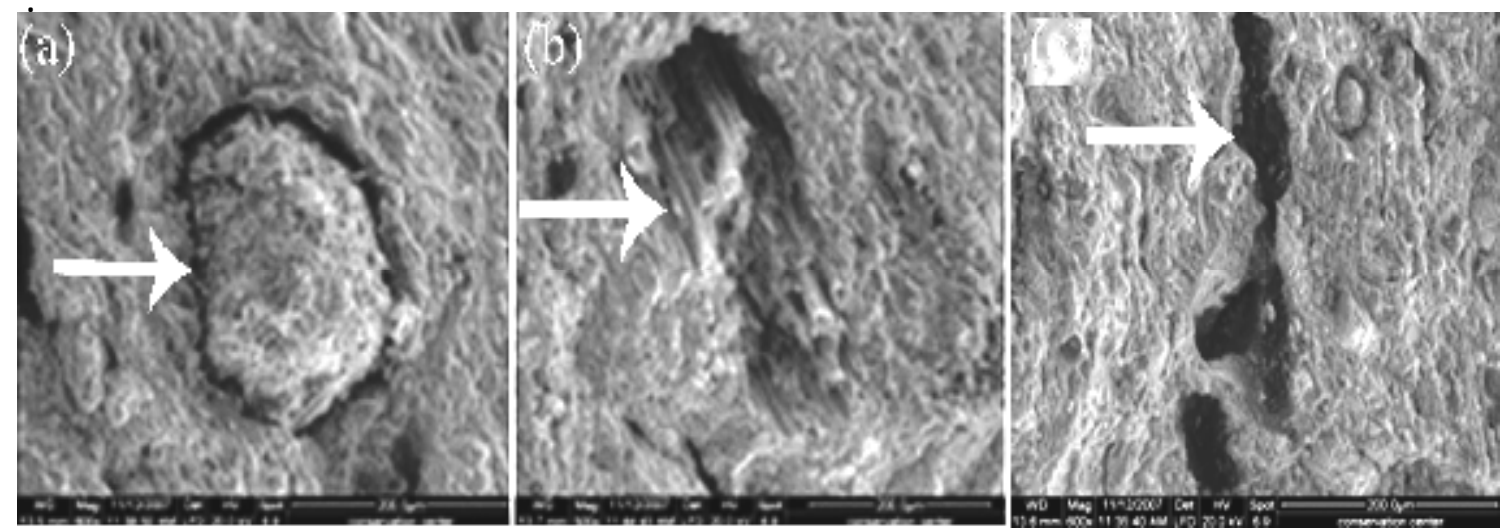

Figure (9) Scanning microscope images of the first mould, (a) the pottery fabric added to the clay (500x,), (b) the existing gaps and plant residues $(600 \mathrm{x})$, (c) the presence of some gap (400x).
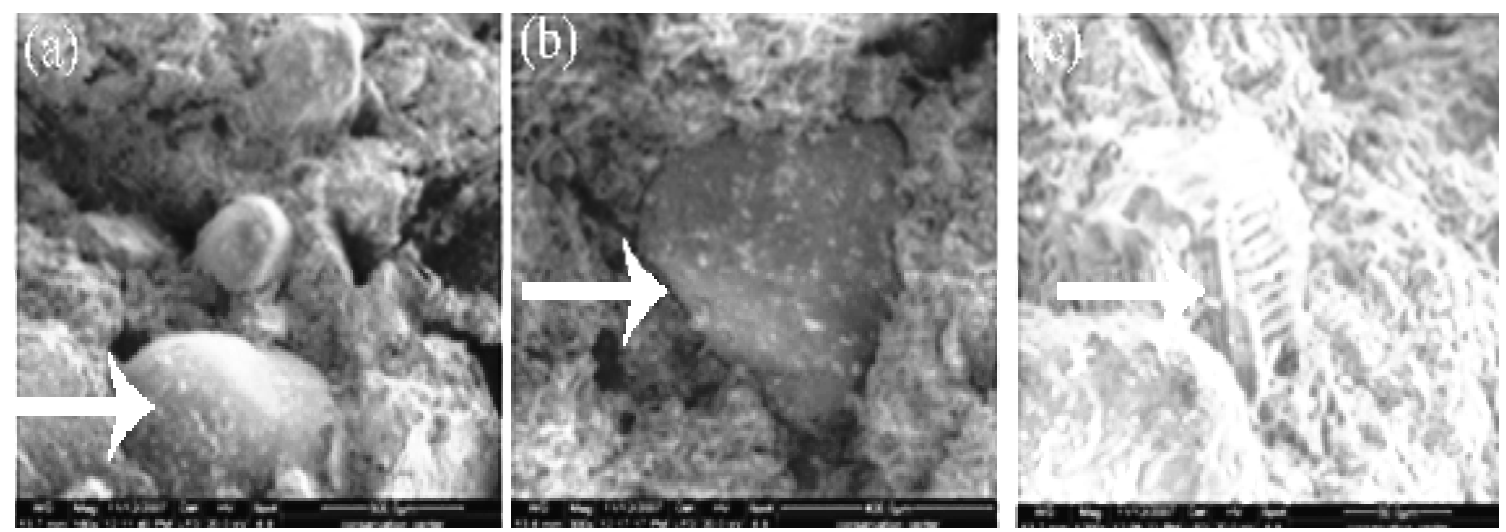

Figure (10) Scanning microscope images of the second mould, (a) the quartz grains were not ground enough (160x), (b) the broken pottery added to the clay (300x), (c) some plant residues (1200x).

\subsection{X-ray Diffraction Analysis}

$X$-ray diffraction instrument model Philips, usage conditions: Diffractometer type: PW 1840Generator tension was used to study the mineralogical composition of the pottery all resulted $(\mathrm{KV}): 40$ Generator current $(\mathrm{mA}): 25$ it data are listed in table (1)

Table (1) shows X-ray diffraction pattern of the two bread moulds

\begin{tabular}{|l|l|l|l|l|}
\hline \multirow{2}{*}{ Minerals } & \multicolumn{2}{c|}{ First Mould } & \multicolumn{2}{c|}{ Second Mould } \\
\cline { 2 - 5 } & \multicolumn{1}{|c|}{ Mineral } & \multicolumn{1}{c|}{ Chemical Formula } & \multicolumn{1}{c|}{ Mineral } & \multicolumn{1}{c|}{ Chemical Formula } \\
\hline Major & Quartz & $\mathrm{SiO}_{2}$ & Quartz & $\mathrm{SiO}_{2}$ \\
\hline Minor & Anorthite & $\mathrm{CaAl}_{2} \mathrm{Si}_{2} \mathrm{O}_{8}$ & Trydimite & $\mathrm{SiO}_{2}$ \\
\hline Traces & $\begin{array}{l}\text { Trydimite } \\
\text { Magnetite }\end{array}$ & $\mathrm{SiO}_{2}$ & $\begin{array}{l}\text { Orthoclase } \\
\text { Magnetite }\end{array}$ & $\mathrm{KalSi}_{3} \mathrm{O}_{8} \mathrm{Fe}_{3} \mathrm{O}_{4}$ \\
& $\mathrm{Fe}_{2} \mathrm{O}_{3}$ \\
\hline
\end{tabular}

\section{Results}

\subsection{Polarizing Light Microscope}

Figure (7-a) describes the first pottery mould and shows a lack of uniformity in the size of grains of quartz in the fabric of pottery with a higher proportion of iron 
oxides with the presence of mica particles (P.L.4.X). (7- b) describes the first pottery mould showing the view of the quartz grains scattered in the burned clay, which indicates a lack of coherence and lack of a good grinding with grains of powder, broken pottery that were added to the clay at the setting in addition to mica (P.L.4.X). Figure (8-a) describes the second pottery mould showing the sharp corners of the quartz grains, which indicates the good grinding with the presence of iron oxides and mica grains (P.L. 10X). (8-b) describes the second pottery mould with non-homogeneous quartz grains and iron oxides that give the color of pottery (C.N. $4 \mathrm{X})$.

\subsection{Scanning Electron Microscope examination}

The first pottery mould investigated by SEM describes the existing gaps and heterogeneity in the fabric of pottery strongly with the presence of plant residues within the pottery which shows the lack of precision in the burning by magnification of $500 \mathrm{X}$. figure $(9-\mathrm{a})$. in addition, it shows a fracture within the pottery fabric added to the clay. This highlights the lack of homogeneity in the tissue by magnification of $600 \mathrm{X}$, figure (9b). Finally, proved that there are some

\subsection{X-ray Diffraction Analysis}

The results indicate that this clay has the presence of a high proportion of silica in the form of either filler or as a part of the composition of a metal [13]. Quartz $\left(\mathrm{SiO}_{2}\right)$, one of the most important minerals is a pure silica and metal acts in some objects as an aid to fusion, but in the case of the studied sample it is a thermal material where silica starts melting at 1600 ${ }^{\circ} \mathrm{C}$ and completes melting at $1780{ }^{\circ} \mathrm{C}$ [14]. Trydimite $\left(\mathrm{SiO}_{2}\right)$, It is also a form of silica, when burning the clay contains a gaps on the surface and it can be seen by naked eye 400X, figure (9-c). The second investigated mould by SEM describes some of the quartz grains that were not ground magnification $160 \mathrm{X}$, figure (10-a) and describes some of the broken pottery (grog) added to the fabric of pottery and the magnification $300 \mathrm{X}$, figure (10-b), moreover, describes the tissue as heterogeneous and some plant residues magnification 1200X figure (10-c)

high proportion of silica quartz to become Trydimite at temperatures between 780 $1470{ }^{\circ} \mathrm{C}$, resulting in a renewed and rearrangement crystallization. This transformation is not irreversible. Anorthite $\left(\mathrm{CaAl}_{2} \mathrm{Si}_{2} \mathrm{O}_{8}\right)$ Hematite $\left(\mathrm{Fe}_{2} \mathrm{O}_{3}\right)$ and Magnetite $\left(\mathrm{Fe}_{3} \mathrm{O}_{4}\right)$ High proportion of red iron oxides is attributed to reddish brown color of the pottery. [15]. Also a group of metallic materials such as quartz and impurities such as sulphate and dolomite are present [16].

\section{Treatment and Conservation Methods for the Selected Objects.}

\subsection{Mechanical cleaning}

The pottery dose not have a lot of problems, such as the presence of dust and some parts of adherent surface. So,

mechanical cleaning was done using brushes and scalpels to remove stick and loose dust, fig. (11)

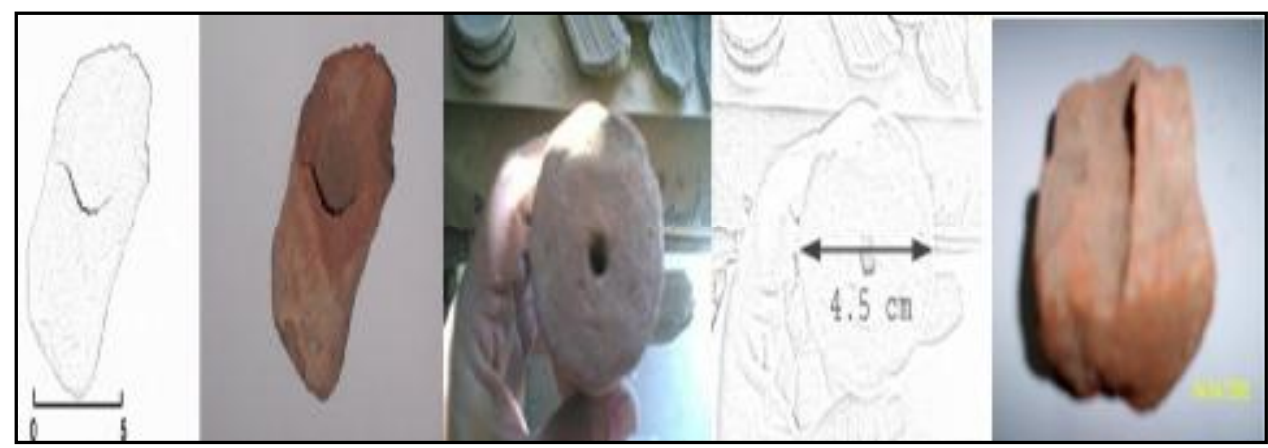

Figure (11) Shows the two bread moulds during cleaning. 


\subsection{Completion of Lost Part}

Objects under study have the base or part of the base, but we do have the end of the bread molds that is making the process of reconstruction a difficult process where completion here is on the basis of previous study of these pieces in the manner of formation and use, as well as the thickness of the object and the direction of restructuring and other. The reconstruction was done in a manner similar to the way of the shaping of the proposed deliberate and simple access to a part similar to the original part.

\subsection{The material used in the reconstruction}

Some experiments were done to gain an access paste that can give specifications which closely resemble its original pottery form and allow the formation similarly. These materials need molding, give a smooth sleek surface far away from of the original surface and that manufactured manually. Hence, Elastic that can be manually shaped was chosen, becomes hardened after the dryness with limited shrinkage and is characterized by its suitable color that can be re-colored, either during or after processing. This elastic dough could be recovered with less mechanical force than the original body.

\subsection{Advantages}

The missing parts from the pieces under study were formed by the free hand formation. It is noticeable to leave marks of the fingers, particularly from outside, as in the archaeological piece. It was noted that it is inseparable from the

\subsection{Coloring}

Some coloring experiments were made on pieces of the dried dough to reach the appropriate color using acrylic reversible
Moreover, it does not affect the archaeological piece chemically because it is made of natural materials, mostly like pottery. Pottery powder (Grog) 60\%, Phenolic Microballons with brown color $40 \%$, and paraloid B. $72.30 \%$ in acetone [17]. It is mixed with water until dough becomes elastic with easy configuration ability. Pottery powder (Grog) a crushed mature and smooth pottery. The used type is thermal mud burns on a high degree of temperature. Phenolic Microballons: It does not shrink with the speedhardening. $3.4 \%$

archaeological piece after completing the restructuring and dryness, fig. (12), Follow-up of the pieces during drying at room temperature, whose defects may appear in the completed portion, must be done.

colors. The color has been applied to the complementary part of the artifact, fig. (13).

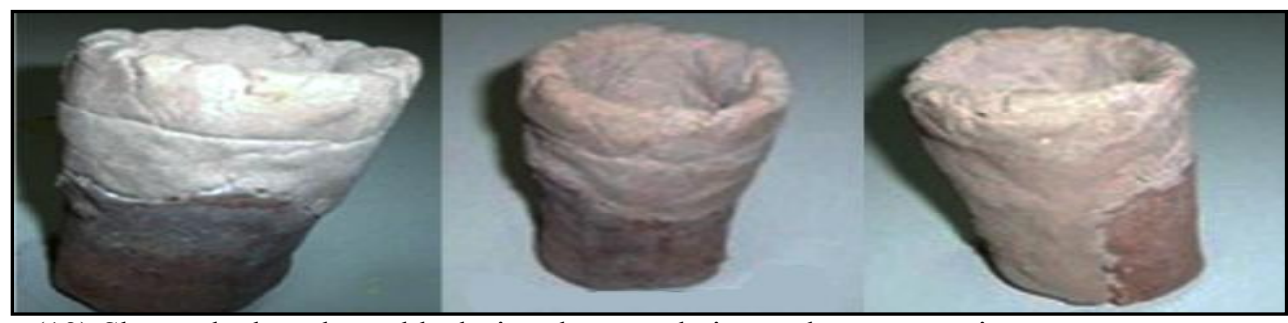

Figure (12) Shows the bread moulds during the completion and reconstruction.

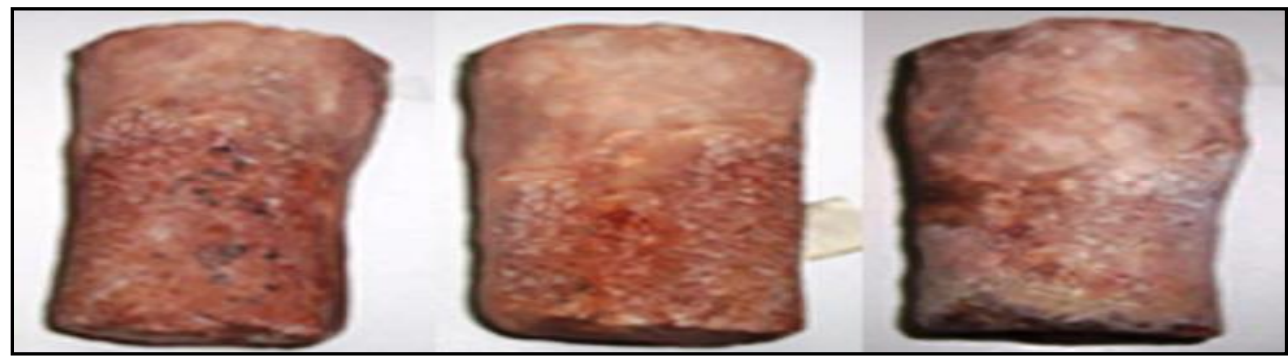

Figure (13) Shows the final form of the two bread moulds after completion and coloring. 


\section{Discussion}

This is an analytical study of the pottery moulds dated to the Middle Kingdom (2040-1782 B.C) in Matriya region. Which is considered an important city in Egyptian history where it belongs to the city of Hilopolis with a long history extending through different Egyptian ages, characterized by many religious buildings and industries, including pottery? Using Polarizing Microscope was possible to identify the mineralogical composition of the studied pottery objects. The weaving of potters ,the gaps can be seen easily, the particles of old pottery, the grains of quartz quality grinding used in the preparation process, and less homogeneity in the tissue when preparing the clay and also not to use the wheel in forming some pieces. In terms of the raw materials used, the use of Xray diffraction (XRD) helped in identification of the components of pottery through the crystalline compounds. In addition, it revealed the mineral changes occurred during burning the clay, which indicated the burning temperature of pottery that affects the crystal phases of metals in the clay during burning. From the minerals identified; Anorthite, Trydimite, magnetite, ferric oxide, potassium silicates and aluminum silicate were found. In addition, quartz could be naturally found in the clay or deliberately added. From these revealed minerals, we conclude that all the pottery was made of Nile clay containing quartz, potassium silicates, aluminum silicate (Orthoclase) in addition to Trydimite which might be classified as one of the crystallized silica phases formed as result of burning calcareous clay between $\left(870-1470{ }^{\circ} \mathrm{C}\right)$. Using the Scanning Electron Microscope, the internal structuring composition of the fabric of pottery could be determined. Homogeneity with the appearance of some gaps, plant debris and, the shape of grains in terms of coherence and fragmentation, and all these are the advantage of the pottery of the Nile C type [18]. From the treatment and maintenance aspects, it is obvious that starting with the mechanical cleaning is always the best way gives .Bringing it to the highest possible degree before starting the chemical cleaning in its different forms is important. This method has successfully removed dust and salts. Completion was done by using Grog which is the fine powder of pottery with Phenolic Micro balloons with brown color having the same properties of clay.

\section{Conclusion}

The petrographical and mineralogical analyses and their analytical data allowed not only the characterization of these pottery bread moulds, but also the formulation of some hypotheses regarding their specific manufacturing techniques. Technology, manufacture, materials used of the Middle Kingdom bread moulds located in Mataryia and Ain shams region could be summarized as follows.

- The pottery analyzed is found to be a domestic pottery moulds that were used in their daily life.

- It was also found that the texture of the pottery was made using Nile $C$ fabric which is characterize with a large quantity of medium to coarse plant residues and high porosity which is suitable for manufacturing these types of moulds.

- The addition of some materials such as sand and pottery fragments is to improve the moulds properties of the moulds, these materials are known as temper or filler.

- The moulds were handmade shaping, and their colors vary between reddish to brown due to the presence of iron oxides mainly hematite and magnetite.

- The presence of trydimite indicated that the firing temperature was above $870{ }^{\circ} \mathrm{C}$. and the hardness of the pottery is medium. 
- The two moulds were fully restored using some conservation materials and scientific methodologies including cleaning, construction, completion and coloring using traditional materials such as grog and Phenolic Microballoons.

\section{References}

[1] Redford, B, (2001) .The Oxford encyclopedia of Ancient Egypt, Vol.

2, The AUC, Egypt, pp: 88-90.

[2] Saleh, A, (1991). Excavations at Hilopolis, Cairo, Egypt, pp: 309312.

[3] Balbouch, M, (1976) General Soundings in Heliopolis in 1971. GM 22, pp: 65-70.

[4] Abd El. Gilil, M, Shaker, and Raue, D, (1996) Recent Excavation at Heliopolis, Orientalia, vol.65, p.136.

[5] Mahmed, A, N, Faobert, G, Schiestl, R and Raue, D, (2008) Pottery of the Meddle Kingdom and the Second Intermediate Period from Hilopolis, SCA, from 2000-2002, MDAIK 64, p. 160 .

[6] Laslo, K, (1977) Hilopolis.In Lexicon der Agyptologie, 2, Wiesbaden.pp1111-1113

[7] Nicholson, P, T. Patterson, H, L, (1985) Pottery making in Upper Egypt, an ethno archaeological study.WA, Vol. 17, p. 39.

[8] Lucas, A, (1962) Ancient Egyptian Materials and Industries, Fourth Edition, London, pp. 18-20.

[9] Mattson, S, (2003) The Complete Potter, Copyright, p.45.

[10] Paice,P, (1989) The Pottery of Daily Life in Ancient Egypt, The Journal of The Society for The Study of Egyptian Antiquities, JSSEA, vol. XIX, pp: 67-73.
[11] Merchand, S, (2004) Fouilles Reunles Dans La Zone Vrbuire de Dendara, CCE7, pp, 211-238.

[12] Arnold, D, Bourriau, J. D (1993) An Introduction to Ancient Egyptian Pottery, Germany, Berlin, p.169.

[13] Veld, B, C, Durc, I, (1998) Archaeological Ceramic materials, Origin and Utilization, Springer, pp.44-47.

[14] Hamer, F, (1991) The Potter's Dictionary of Materials and Techniques, A \& C Black. London, pp. 122-124.

[15] Reedy, C, L, (2007) Thin-Section Petrography of Stone and Ceramic Cultural Materials, London, p.141.

[16] Nicholson, P. T, (2000) Ancient Egyptian Materials and Technology, London, p. 183.

[17] Appolonia, L, (2000) Lectures in pottery and ceramic, Euro-Med course on materials technologies for the conservation of cultural heritage consisting of ceramic, Perugia, Italy, Sep. $28^{\text {th }}-$ Oct. $4^{\text {th }}$, 2000.

[18] Buys, S \& Oakley, V, (1996) The Conservation and restoration of Ceramic, Victoria \& Albert Museum, London, pp. 85-86. 